\title{
Geographic Information System of Dengue Hemorrhagic Fever Area Mapping in the City of Samarinda
}

\author{
Tarsius Aloysius Pedor \\ Software Engineering Technology, \\ Agricultural Polytechnic of \\ Samarinda, Samarinda, 7542, \\ Indonesia \\ aloysiuspedor@gmail.com
}

\author{
Syafei Karim (10* \\ Software Engineering Technology, \\ Agricultural Polytechnic of \\ Samarinda, Samarinda, 7542 , \\ Indonesia \\ syfei.karim@gmail.com \\ *Corresponding author
}

\author{
F.V Astrolabe Sian Prasetya \\ Geomatics Technology, \\ Agricultural Polytechnic of \\ Samarinda, Samarinda, 7542, \\ Indonesia \\ astrolabesp@politanisamarinda.ac.id
}

Received: 2021-09-30; Revised: 2021-10-01; Accepted: 2021-10-25; Published: 2021-12-01

\begin{abstract}
Dengue Hemorrhagic Fever (DHF) is still one of the main public health problems in Indonesia. This disease can threaten public health, efforts to prevent its spread need to be done. As the first step for prevention, it is necessary to do the mapping. Environmental factors have a major influence on the increase and transmission of mosquito-borne diseases such as DHF. The most influential factors include the physical environment consisting of rainfall, air humidity, and population density. The city of Samarinda itself has not maximized the DHF control program, because the government is less effective in mapping the DHF-vulnerable areas based on indicators of increasing cases over the last few years using spatial maps. Mapping the DHF area with the spatial method can maximize the implementation of the DHF control program, the implementation of the fogging program, and other DHF control programs. So to get this information, a geographical information system (GIS) is needed or commonly known as a geographic information system (GIS). This web-based geographic information system application for mapping dengue areas can display detailed information such as the address of the Public Health Center that provides information on the number of cases that occur in each sub-district and a polygon map showing which sub-district has the most cases.
\end{abstract}

Keywords - Geographic Information System, Dengue Hemorrhagic Fever, Environment.

\section{INTRODUCTION}

Dengue Hemorrhagic Fever (DHF) is still one of the main public health problems in Indonesia (Kemenkes 2010). This disease can threaten public health, efforts to prevent its spread need to be done. As the first step for prevention, it is necessary to do the mapping. Environmental factors have a major influence on the increase and transmission of mosquito-borne diseases such as DHF. The most influential factors include the physical environment consisting of rainfall, humidity, and population density. The physical environment can directly affect the mosquito breeding habitat which is the origin of the cause of dengue disease (Roziqin and Hasdiyanti 2017).
The study area for this Dengue Fever case study is Samarinda City, East Kalimantan Province, which is located on the Mahakam River, which has led to developments in the economic, socio-cultural, agricultural fields, as well as the mobility of its people. These conditions have an impact on the environment and public health.

The city of Samarinda itself has not maximized the DHF control program, because the government is less effective in mapping dengue-prone areas based on indicators of increasing cases over the last few years using spatial maps (Syamsir, Daramusseng, and Rudiman 2020).

Geographic Information System (GIS) is a series of systems that utilize digital technology to perform spatial analysis such as analyzing the condition of an area to determine the actions that must be taken to deal with the disease. This Geographic Information System is designed to provide easy data storage for dengue fever sufferers, making it easier to identify and search (Information, Gis, and Kota 2015).

Making this map application using the Leaflet application and the data is presented in the form of spatial data and attributes that are displayed in the form of a map.

The purpose of this study is to create a web-based geographic information system (GIS) that can provide information on the number of dengue patients around the user's location. The expected result is that this GIS application can make it easier to provide information to the public, both from within and outside the city. About the number of dengue fever sufferers in the city of Samarinda.

\section{LITERATURE REVIEW}

I Wayan Rustana Putra Yasa, I Gusti Lanang Agung Raditya Putra, I Putu Agus Swastika, 2013 Information System for Informatics \& Computer Management College (STMIK Primakara) entitled Geographic Information System for Mapping Chronic Diseases and Dengue Fever at Health Center 1 Baturiti Web-Based. Information technology has become very commonplace and a necessity in all aspects of life (Citra Kunia putri dan trisna insan Noor 2013). 
Finally, Ristanto Kaunang, Wulan P J Pandelaki, A J, 2015 Faculty of Medicine, Medical Sciences, Faculty of Medicine, University of Sam Ratulangi Manado entitled Mapping of Dengue Hemorrhagic Fever Cases in North Minahasa Regency. Dengue hemorrhagic fever (DHF) is an acute febrile disease found in the tropics with a geographic distribution similar to malaria. Dengue fever is caused to humans by the Aedes Asegypti mosquito. From the data from the Health Office of North Minahasa Regency in 2013, there were 129 patients who died as many as 3 people. Data from January 2014 as many as 66 patients (Faldy, Kaunang, and Pandelaki 2015).

Riska R. S, Ronald I. Otay, Wulan P. J. Kaunang, 2015 Faculty of Medicine, Medical Sciences, Faculty of Medicine, University of Sam Ratulangi Manado entitled Mapping the Spread of Dengue Hemorrhagic Fever Using Geographic Information System (GIS) in Kotamobagu City. Dengue hemorrhagic fever (DHF) is an infectious disease caused by the dengue virus from the bite of the Aedes Aegypti mosquito and sporadically it always becomes an Extraordinary Event (KLB) every year. Geographic Information System (GIS) is a series of systems that utilize digital technology to support the epidemiological investigation of dengue disease and also as a tool to monitor regional conditions for dengue disease (Information, Gis, and Kota 2015).

Arif Roziqin, Fitri Hasdiyanti, 2017 Batam State Polytechnic Geomatics Engineering Study Program entitled Regional Mapping of Dengue Hemorrhagic Fever (DHF) on Batam Island. Dengue Hemorrhagic Fever (DHF) is a disease caused by a virus that is spread by the Aedes Aegypti mosquito. This study aims to map the distribution of dengue fever areas on Batam Island. This study uses secondary data by providing attributes and assessments based on physical parameters that are considered to cause dengue fever. The parameters of DHF are rainfall, air humidity, and a population density which directly affect the habitat for the development of the Aedes Aegypti mosquito. The data used is secondary data obtained from the Central Statistics Agency (BPS) Batam City in 2015 (Roziqin and Hasdiyanti 2017).

Veritawati, Ionia; Nova, Steffi; Mastra, Riadika, 2020 Informatics Engineering at Pancasila University Jakarta entitled Information System for Mapping Dengue Fever Disease Based on Geographic Information. One of the health problems that often occurs in Indonesia is dengue hemorrhagic fever (DHF). Dengue hemorrhagic fever is one of the public health problems in Indonesia which tends to spread widely and the rate of outbreaks is getting higher, even reaching extraordinary events. One of the cases is in the Bekasi district, especially in the South Tambun sub-district. To monitor the spread of the disease, it is necessary to build a web-based information system that provides information about mapping the spread of dengue fever (Veritawati, Ionia; Nova, Steffi; Mastra 2020).

A. Geographic Information System (GIS)

Geographic Information System (GIS) or Geographical Information System (GIS) is a computerbased information system, designed to work using data that has spatial information (spatial reference). Geographic information systems can capture, check, integrate, manipulate, analyze, and display data that are spatially referenced to the condition of the earth.

\section{B. Dengue Fever}

Quoted from research (Yuniarti, Sudarsono, and Wijaya 2014) Dengue fever (Dengue fever, DF) is a disease that mainly occurs in adolescents or adults, with clinical signs of fever, muscle aches, and/or joint pain accompanied by leukopenia., with/without rash and lymphadenopathy, biphasic fever, severe headache, pain on eye movement, impaired taste, mild thrombocytopenia, and spontaneous petechiae.

\section{Samarinda City}

Samarinda City is the capital of East Kalimantan Province. The city of Samarinda is directly adjacent to the Kutai Kartanegara district which is one of the districts rich in natural resources and is one of the areas that contributes a lot of foreign exchange to the Unitary State of the Republic of Indonesia (NKRI). The area of Samarinda City is $718.00 \mathrm{~km} 2$ and is located between 117003'00" East Longitude and 117018"14" East Longitude and between 00019'02" South Latitude and 00042'34" South Latitude.

\section{Leafleat}

The leaflet is generally an open source javascript library that is useful for building web-based interactive map applications. Leaflet supports mobile platforms and desktop platforms, HTML5 and CSS3 as well as OpenLayer and Google Maps API which are javascript libraries for building map applications that are very popular today.

\section{E. SUS (System Usability Scale) method}

The SUS method is one of the most popular usability testing tools. SUS was developed by John Brooke in 1986. This SUS is a reliable, popular, effective, and inexpensive usability scale (Saputra 2019).

\section{RESEARCH METHODS}

This research was carried out within 6 months, starting from the preparation of the proposal until the completion of the research from October 2020 - March 2021. The place of research was carried out at the Samarinda City Health Service.

The tools used by hardware (hardware) and software applications (software) are as follows:

1. Hardware:

a. Asus Laptop (i3 Processor, 4GB RAM)

2. Software:

a. XAMPP version 7.4.32.-0

b. Laravel 7 framework

c. Sublime Text version 3

d. Microsoft Office (Word, Visio) 2019

e. Leaflet version 1.8

3. Ingredients
a. District Administration Boundary Data Source: Google Earth
b. DHF data 


\section{Data Source: Samarinda City Health Office}

\section{A. Research procedure}

In this study, the stages of making a web-based geographic information system for the location of the Dengue Fever Region in Samarinda City used the waterfall method. The waterfall method or the so-called waterfall method where it describes a systematic and sequential approach in building a system, as in picture 1 .

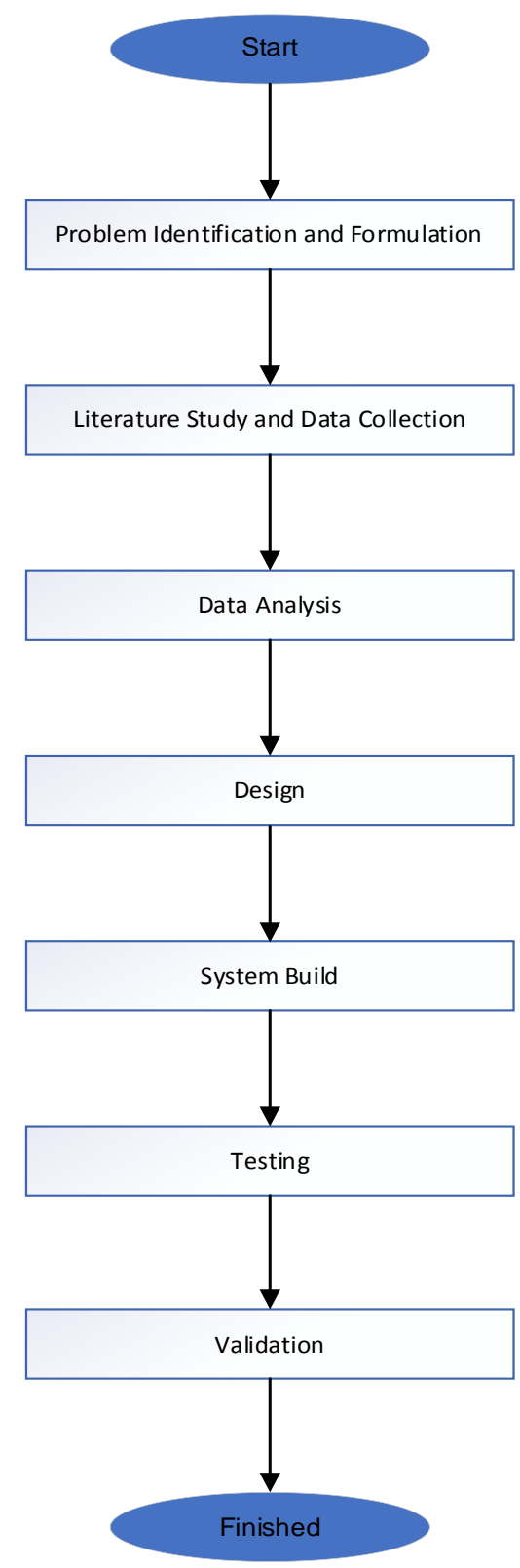

Picture 1. Research Method
What problems arise in this research, and these problems are formulated as follows:

a. How to provide information on Dengue Hemorrhagic Fever to users?

b. How to make a web-based geographic information system for Dengue Hemorrhagic Fever in the city of Samarinda?

2. Literature Study and Data Collection

The Literature Study carried out aims to make it easier to determine the data analysis method to be used based on previous research and data collection is the initial stage in carrying out the development process in the system to be created, while the data collection process is by submitting a referral letter to the Samarinda City Health Office to get the amount Information on DHF sufferers and make a questionnaire.

3. Data Analysis and Map Overlay

The data analysis carried out here determines what kind of data I will input into the system and the overlay is used to display a digital map along with its attributes and produce several combined maps that have attribute information from several of these maps.

4. Design

System Design helps in hardware, system requirements and also helps in defining the overall system architecture.

5. System Build

Making a system that is carried out to create a mapping information system application with the web that runs well. Making this system is the main stage because at this stage the system development process can solve problems and process the data that has been collected. At this stage, the process of the design results that have been made is implemented.

6. Testing

At this stage, the system testing process is carried out to find out whether the system is running well or not, if there is a problem with the system, a redesign of the system will be carried out to fix the problems that occur.

7. Validation

At this stage, a validation process is carried out which consists of:

a. Data Authenticity

At this stage is checking and matching the data whether it is appropriate or not.

b. Application

At this stage, it is done to find out whether the application made has provided benefits and convenience to the user by conducting a questionnaire.

1. Problem Identification and Formulation

This stage is the initial step for research, namely the identification and formulation of the problem.

\section{B. System Design}

The following is a web-based design of the application system for the geographic information system 
of the Dengue Hemorrhagic Fever Region in the city of Samarinda.

1. Data Flow Diagram (DFD) level 0

In the picture, there is one process, namely the Web-Based Regional Geographic Information System for Dengue Hemorrhagic Fever and there are two entities, namely admin and user, as in picture 2

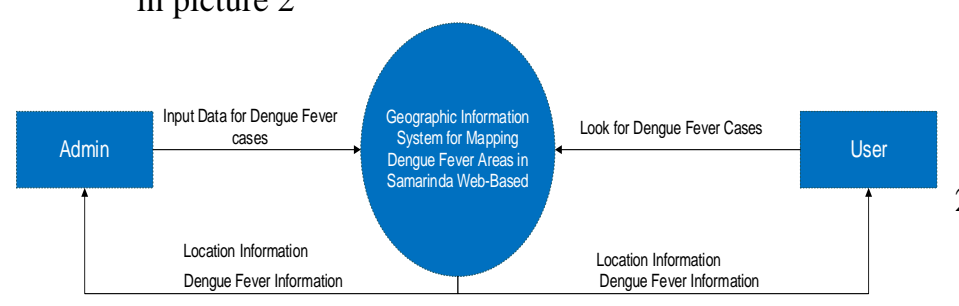

Picture 2. DFD Level 0
GIS Regional Mapping of Dengue Hemorrhagic Fever (DHF) is a system that provides information to users about the distribution of DHF.

b. Entity

1) Admin

Admin fully manages to input, editing, deleting and updating DHF data.

2) User

The user searches for information about DHF and the total number of each subdistrict.

2. Data Flow Diagram (DFD) level 1

In the picture, it can be seen that there are two entities, namely admin and user, there are six processes, namely login, homepage, DBD map, profile, and map location as in picture 3

a. Process

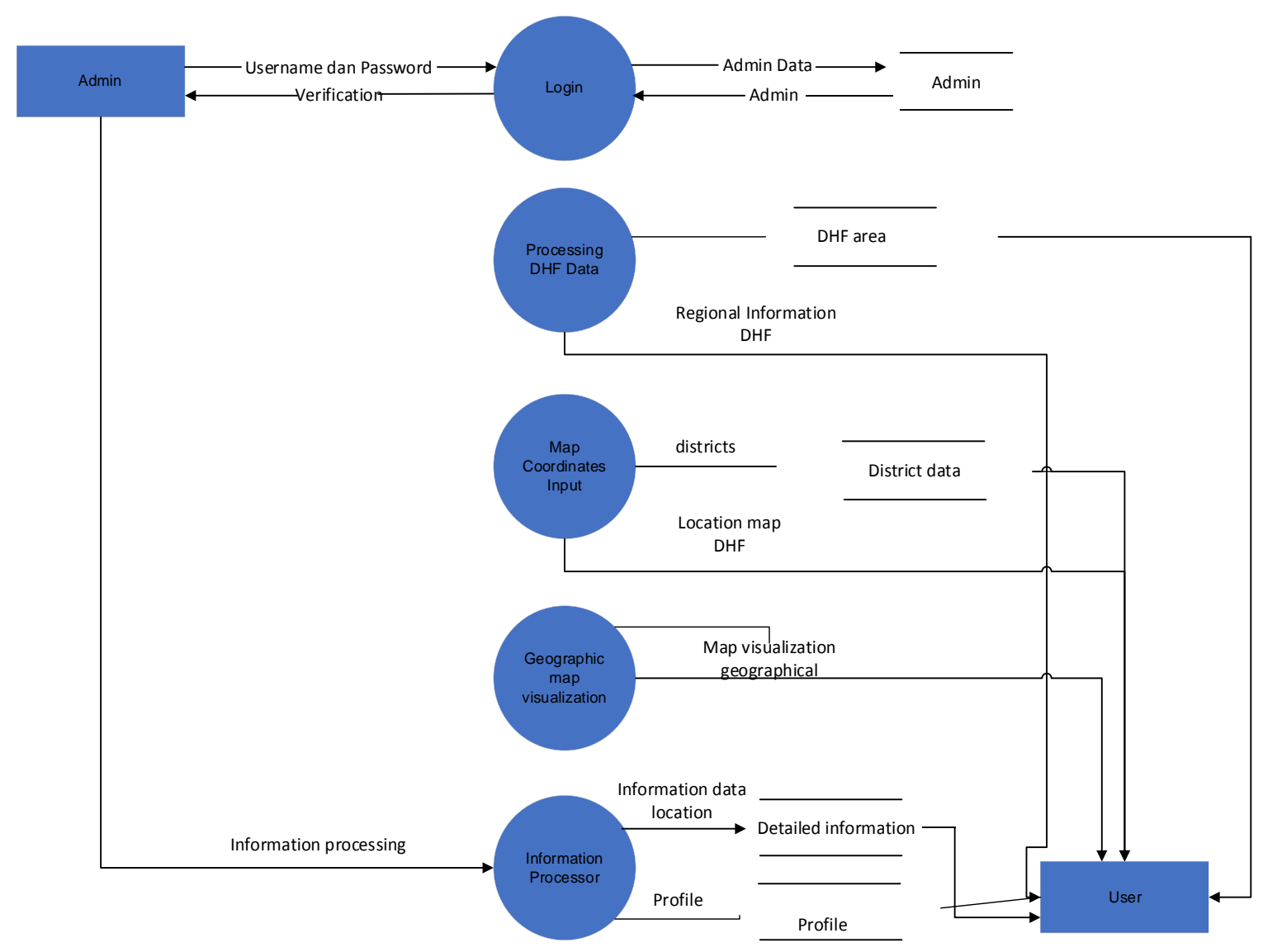

Picture 3. DFD Level 1

a. Admin tasks as follows:

1) The admin inputs the admin data username and password which is used as a login account by the admin and will be processed by the login system and then forwarded to the admin data store.

2) Admin manages the appearance of the homepage design and adds detailed information about DHF so that users can better understand and understand the information.

3) Admin inputs, edits, deletes, and updates spatial and non-spatial data, and then it will be processed by the DHF map system and will be continued into spatial and non-spatial data stores. 
4) Admin adds information about profile into profile system.

b. User Tasks

The user sees the location information for DHF displayed in the map by hovering the cursor over the District and its Point to see in detail the DHF information.

\section{RESUlts AND DisCUSSION}

1. Application Development Results

The results of the Web-Based Geographic Information System application for Dengue Hemorrhagic Fever Area Mapping in Samarinda City are as follows:

a. Home View

The home page will display statistics on the number of people affected by dengue fever per year and the latest news about dengue as shown in Picture 4.

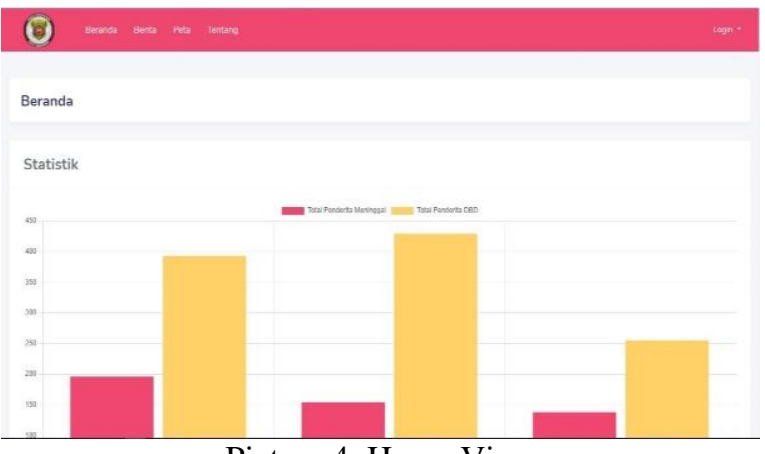

Picture 4. Home View

b. News View

The news page displays news related to dengue as shown in the picture 5 .

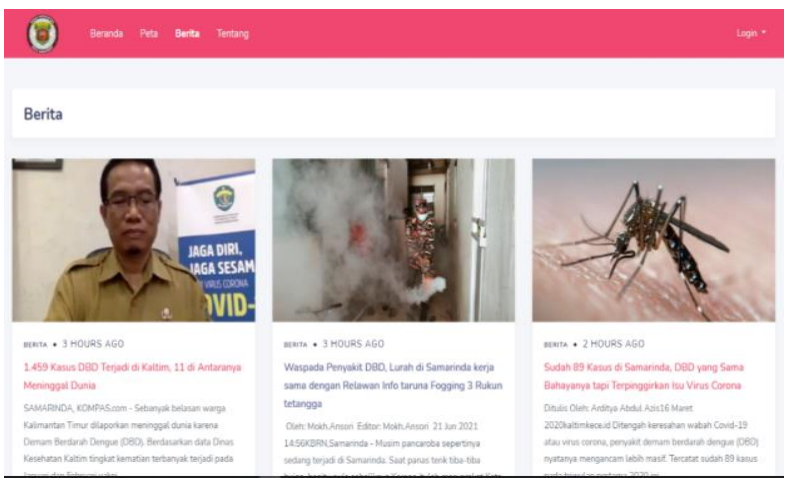

Picture 5. News View

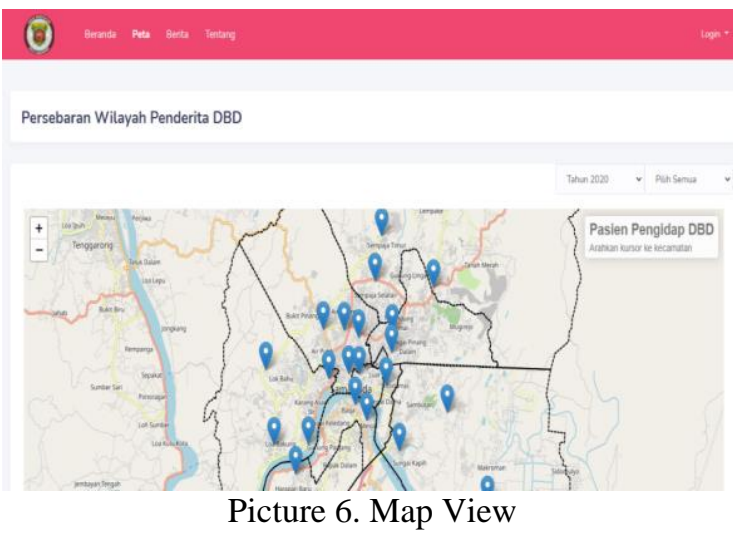

d. Profile View

This page displays information about the maker of this application as shown in picture 7 .

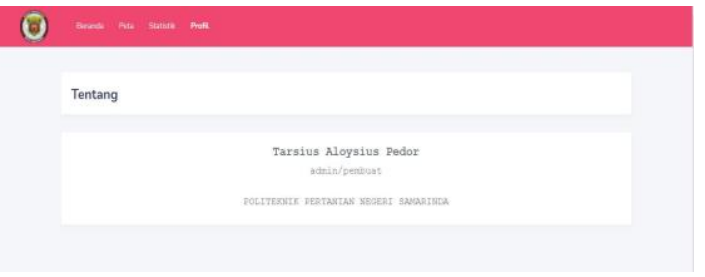

Picture 7. Profile View

e. Login View

On this login page, it displays the admin email and password that can access the data as shown in the picture 8 .



f. Case Data Page

The DHF Case data page displays a table that provides information on Public Health Center, the number of cases, and the number of deaths. On this page, there is also an add data button, besides that there are also two actions, namely editing and deleting data as shown in the picture 9. c. Map View

Displays a map with the location of the Public Health Center containing detailed incident information that has been inputted as shown in picture 6. 


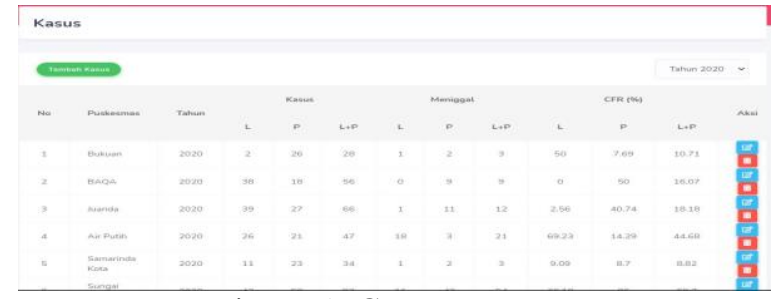

Picture 9. Case Data Page

g. Add Case Data Page

The Add Data page displays a form to input new data and on this page, there is a save and return button as shown in the picture 10 .

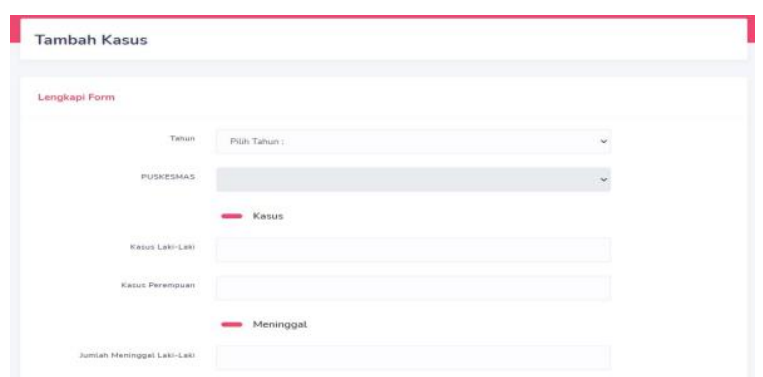

Picture 10. Add Case Data Page

h. Case Data Edit Page

The data edit page displays a form to change the data that has been inputted, on this page, there is also a change and return button as shown in the picture 11.

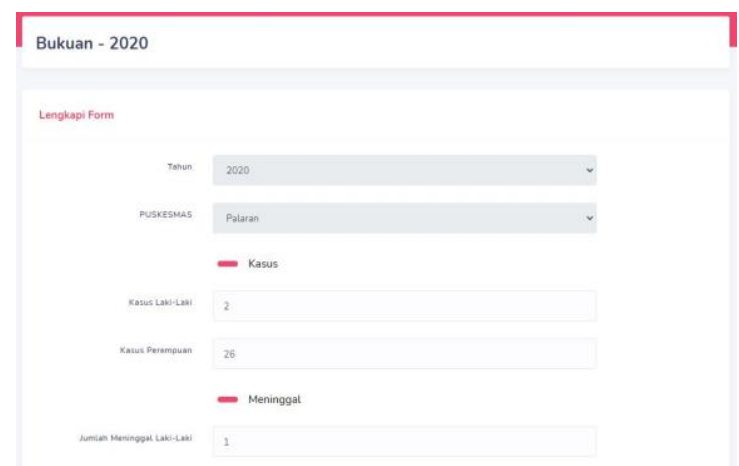

Picture 11. Case Data Edit Page

2. System Test

System testing is carried out to ensure the application runs properly. With this test can also find out the weaknesses of this system. So, if there is an error in the system, it can be repaired. In this test, black box and questionnaire methods are used.

a. User Black box testing

The results of the user Black Box test are as follows as shown in the table 1 .
Table 1. User Black box testing

\begin{tabular}{|c|c|c|}
\hline Testing & Results & Status \\
\hline Home View & $\begin{array}{c}\text { Showing stats \& Latest } \\
\text { News }\end{array}$ & Success \\
\hline Map View & Showing Map & Success \\
\hline News View & Showing News & Success \\
\hline View About & $\begin{array}{c}\text { Showing Creator } \\
\text { Profile }\end{array}$ & Success \\
\hline Login & $\begin{array}{c}\text { Input username \& } \\
\text { Password }\end{array}$ & Success \\
\hline
\end{tabular}

b. Admin Black Box Test

The results of the black box testing are as follows as in the table 2 .

Table 2. Admin Black Box Test

\begin{tabular}{|c|c|c|}
\hline Testing & Result & Status \\
\hline Case & $\begin{array}{c}\text { Input Case } \\
\text { Update Case } \\
\text { Delete Case }\end{array}$ & Success \\
\hline $\begin{array}{c}\text { Public Health } \\
\text { Center }\end{array}$ & $\begin{array}{c}\text { Input Public Health Center } \\
\text { Update Public Health } \\
\text { Center } \\
\text { Delete Public Health } \\
\text { Center }\end{array}$ & Success \\
\hline Districts & $\begin{array}{c}\text { Input Districts } \\
\text { Update Districts } \\
\text { Delete Districts }\end{array}$ & Success \\
\hline Page & $\begin{array}{c}\text { Input Page } \\
\text { Update Page } \\
\text { Delete Page }\end{array}$ & Success \\
\hline News & $\begin{array}{c}\text { Input News } \\
\text { Update News } \\
\text { Delete News }\end{array}$ & Success \\
\hline Category & $\begin{array}{c}\text { Input Category } \\
\text { Update Category } \\
\text { Delete Category }\end{array}$ & Success \\
\hline Admin & $\begin{array}{l}\text { Input Admin } \\
\text { Update Admin } \\
\text { Delete Admin }\end{array}$ & Success \\
\hline
\end{tabular}

\section{CONCLUSIONS}

Based on the results of the reviews and analyzes that have been carried out, the conclusions are This webbased geographic information system application for dengue regional mapping can display detailed information such as the address of the Public Health Center that provides information on the number of cases that occur in each sub-district and a polygon map that displays which sub-district has the more number of cases so that it is easier for users to obtain information and From the test results, 62 respondents regarding this application got a score of 76 , so the score is in the GOOD category with a B grade scale.

\section{REFERENCES}

Citra Kunia putri dan trisna insan Noor, 2013. “済無No Title No Title." Analisis pendapatan dan tingkat 
kesejahteraan rumah tangga petani 53(9): 168999.

Faldy, Ristanto, Wulan P J Kaunang, and A J Pandelaki. 2015. "Pemetaan Kasus Demam Berdarah Dengue Di Kabupaten Minahasa Utara." Jurnal Kedokteran Komunitas Dan Tropik 3(2): 73-81.

Information, Geographic, System Gis, and D I Kota. 2015. "Pemetaan Penyebaran Penyakit Demam Berdarah Dengue Dengan Geographic Information System (Gis) Di Kota Kotamobagu." Jurnal Kedokteran Komunitas Dan Tropik 3(2): 48-56.

Kemenkes. 2010. "Demam Berdarah Dengue." Buletin Jendela Epidemiologi 2: 48.

Roziqin, Arif, and Fitri Hasdiyanti. 2017. "Pemetaan Daerah Rawan Penyakit Demam Berdarah Dengue (DBD) Di Pulau Batam." Jurnal Integrasi 9(2): 106.

Saputra, Ade. 2019. "Penerapan Usability Pada Aplikasi PENTAS Dengan Menggunakan Metode System Usability Scale (SUS) (Usability Implementation in PENTAS Application Using the System Usability Scale (SUS) Method)." JTIM: Jurnal Teknologi Informasi dan Multimedia 1(3): 206-12.

Sasmito, Ginanjar Wiro. 2017. "Penerapan Metode Waterfall Pada Desain Sistem Informasi Geografis Industri Kabupaten Tegal." Jurnal Informatika:Jurnal Pengembangan IT (JPIT) 2(1): 6-12.

Syamsir, Syamsir, Andi Daramusseng, and Rudiman Rudiman. 2020. "Autokorelasi Spasial Demam Berdarah Dengue Di Kecamatan Samarinda Utara, Kota Samarinda." Jurnal Kesehatan Lingkungan Indonesia 19(2): 119-26.

Veritawati, Ionia; Nova, Steffi; Mastra, Riadika. 2020. "Sistem Informasi Pemetaan Penyakit Demam Berdarah Berbasis Informasi Geografis." Journal of Informatics and Advanced Computing 1(1): 1-5.

Wibowo, Koko Mukti, Kanedi Indra, and Juju Jumadi. 2015. "Sistem Informasi Geografis (SIG) Menentukan Lokasi Pertambangan Batu Bara Di Provinsi Bengkulu Berbasis Website." Jurnal Media Infotama 11(1): 51-60. https://jurnal.unived.ac.id/index.php/jmi/article/vie w/252/231.

Yuniarti, U., B. Sudarsono, and A. Wijaya. 2014. "Aplikasi Sistem Informasi Geografis Penyebaran Penyakit Demam Berdarah Dengue Berbasis Web (Studi Kasus : Kabupaten Kudus).” Jurnal Geodesi Undip 3(3): 111-23. 